\title{
ALTITUDINAL DISTRIBUTION OF BRYOFLORA AT CHANDRAGIRI MOUNTAIN FOREST OF KATHMANDU DISTRICT, CENTRAL NEPAL.
}

\author{
NIRMALA PRADHAN \\ Natural History Museum, Tribhuvan University \\ Swayambhu, Kathmandu, Nepal \\ bryonep@yahoo.com
}

\begin{abstract}
S
Chandragiri Mountain forest in Kathmandu borders Makwanpur district to the west was least known for bryophytes till this study was conducted. This mountain forest with varying elevation ranges from 1365 to $2300 \mathrm{~m}$ offered different habitat types for diverse bryofloral species which included 58 species of 39 genera categorized under 27 families and nine orders. Of the recorded species 18 species were rare and five new records to country's list. Sauteria spongiosa (Kashyap) S. Hatt., a rare moss species was not recorded in this study though was reported for the first time at $2250 \mathrm{~m}$ of this mountain in 1982. The habitat of this moss has completely been destroyed now due to expansion of the road in this part.
\end{abstract}

Keywords: diversity, elevation, habitat, liverworts, moss

\section{INTRODUCTION}

Bryoflora of Chandragiri remained an unexplored group till this extensive study was carried out in different months of 2010 to 2012 . The changing pattern of the bio-physical gradients at varying altitudinal habitats displayed a rich diversity of mosses and liverworts in this mountain forest. Phulchowki and Chandragiri are two among the four high ridges bordering Kathmandu Valley.

Dobremez (1996) has described an altitudinal distribution of flora of central Nepal. The eleven ecological levels from the lower tropical (below $500 \mathrm{~m}$ ) to the highest vegetation line (above $5000 \mathrm{~m}$ ) have been mentioned in his study. BPP (1995) has shown the distribution of flowering plants as well as bryoflora, which showed high diversity in the midhills.

Nepal has represented a good diversity of bryoflora which counts 1205 species hitherto and includes all the three classes comprising Hepaticae, Anthocerotae and Musci (Pradhan, 2013). An extensive work of Pradhan (2010) documented 213 species of bryoflora below $1000 \mathrm{~m}$ of elevation in Tarai and Churia range. Pradhan (2011a). also published the diversity record of this plant occurring in different bioclimatic zones which included 312 species in subtropical, 465 species in temperate, 323 species in subalpine, 233 species in alpine and 22 species in the nival zones. Aongstroemia julaecia (Dicranaceae) was collected at $6532 \mathrm{~m}$ of elevation in the Khumbu region of east Nepal. This has been mentioned as the highest limit for bryophytes in the world (Dixon, 1925).

A total of 118 ecosystems have been identified in Nepal (Dobremez, 1970). The natural 
ecosystem ranges from the tall grasslands and marshlands and tropical and sub-tropical broadleaf forests along Tarai and Siwalik foothills to subtropical and temperate broadleaf and conifer forests in the middle Mountains; mixed and conifer forests in the high Mountains; and alpine meadows above the tree line.

Bryophytes are distributed in different bioclimatic zones across low to the highland regions of Nepal. The lowest record of this plant has been made at $62 \mathrm{~m}$ in the Jhapa district where tropical species like Marchantia, Plagiochasma, and Fissidens are fairly common besides epiphytic species like Frullania and Entodontopsis on Shorea robusta trees (Pradhan, 2010). Being a crossing zone of the high and lowland species, the species richness of this plant is high in midland region. Subtropical and temperate species are widely distributed in this part. Similarly, Sphagnum nepalensis, an endemic species is very much localized to the llam district of the east only (Pradhan, 2000).

In drought period the thallus of this plant remains dry and decomposed. In favorable condition when the environment become moist due to rain, vegetative propagation takes place in the old thallus which develops into new thalli. Water is an essential factor for the fertilization in this plant. During wet season, the thallus is transformed into the sporophytic phase followed with sexual reproduction which is accomplished before the onset of winter. Majority of this plant specifically in Chandragiri and other mountains of the midland zone show sporophytic growth during September to the start of November.

\section{STUDY SITE}

Chandragiri mountain to the southwest part is the next highest ridge after the northern Shivapuri Mountain of Kathmandu city. This mountain continues below the valley floor of Kathmandu to the north and Chitlang of Makwanpur district to the west with co-ordinates of $27^{\circ} 27^{\prime} \mathrm{N}$ to $27^{\circ}$ $49^{\prime} \mathrm{N}$ and $85^{\circ} 10^{\prime}$ to $85^{\circ} 32^{\prime} \mathrm{E}$. The elevation of this mountain ranges from $1365 \mathrm{~m}$ to $2300 \mathrm{~m}$ (fig.1). Chandragiri Mountain is a transitory route which connects the districts of Makwanpur and Kathmandu through a broadened motorable road.

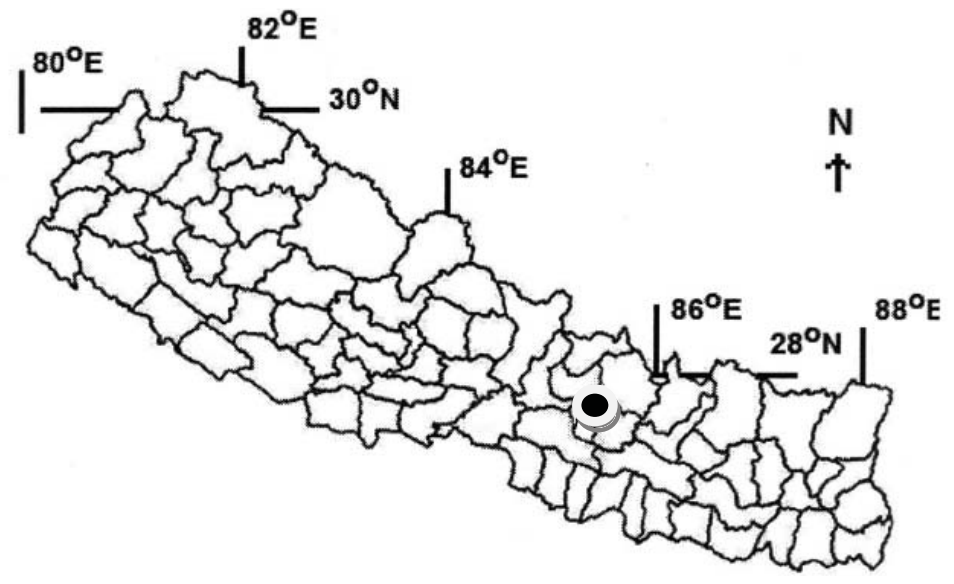

FIG. 1. Map showing the study area. 


\section{Vegetation}

Alnus nepalensis is a pre-dominant species at the lower portion of the Chandragiri Mountain. Common floral species noted in this part are Ligustrum confusum, Schima wallichii, Gravelia robusta, Maesia chisia, Albizzia spp., etc. Other species like, Rhododendron arboreum and Pinus roxburghii are well distributed with a good growth of Schima wallichii. The uppermost limit of $2300 \mathrm{~m}$ displayed the dominancy of Rhododendron arboreum. Other species like Quercus semicarpifolia, Celtis australis, Maesia chisia, Prinscepia utilis, etc. are well distributed in this forest. Pteridophytic distribution is well marked with the presence of Lycopodium cernua, Selaginella indica, Glychenia gigantea, Nephrolepis cordifolia, Lygodium japonicum, Cheilanthes bicolor, Thelypteris dentata, etc. These fern species are associated to different altitudinal habitats of the bryophytes recorded here.

\section{Climate}

Over the course of a year, the temperature typically varied from $3^{\circ} \mathrm{C}$ to $30^{\circ} \mathrm{C}$ and is rarely below $2^{\circ} \mathrm{C}$ or above $32^{\circ} \mathrm{C}$. The warm season lasts from April to October with an average daily high temperature above $27^{\circ} \mathrm{C}$. The hottest day of the year is June, with an average high of $30^{\circ} \mathrm{C}$ and lowest of $20^{\circ} \mathrm{C}$. The cold season lasts from December to February with an average daily high temperature below $21^{\circ} \mathrm{C}$. The coldest day of the year is the month of January, with an average lowest record of $3^{\circ} \mathrm{C}$ and highest of $18^{\circ} \mathrm{C}$ (fig.2).

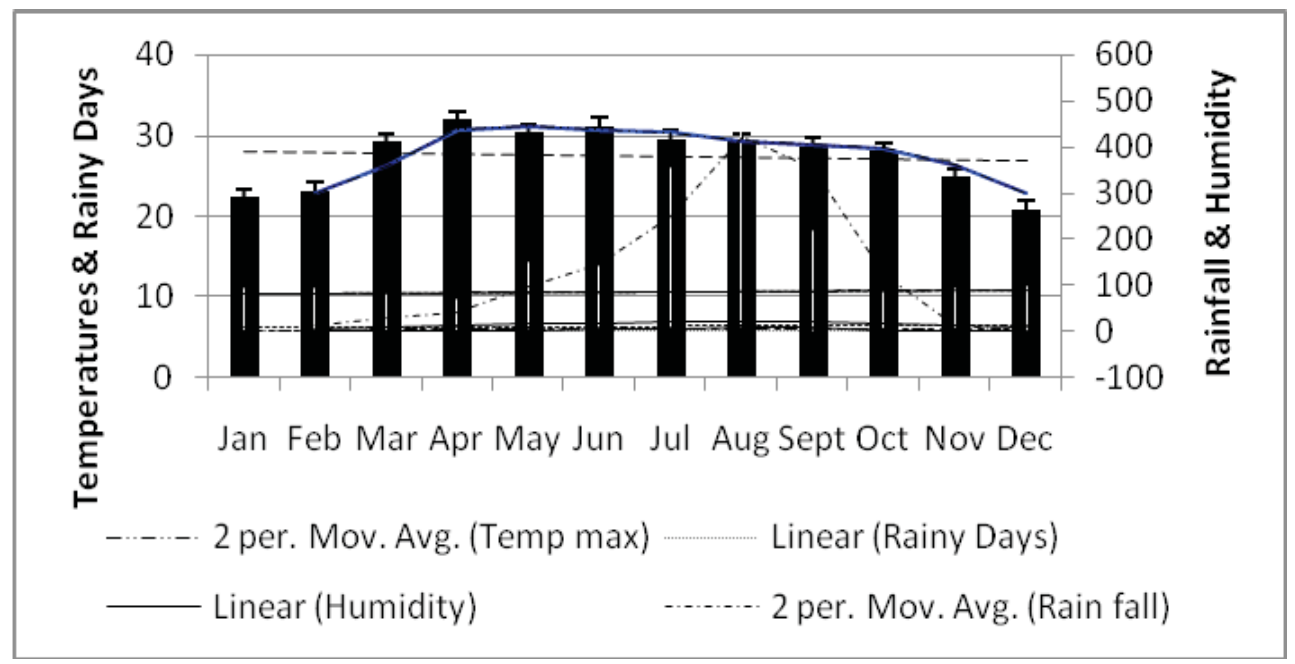

FIG. 2. Climatic pattern of Chandragiri.

\section{MATERIALS AND METHODS}

Study was conducted in various months of the years 2010 to 2012. The months of August to November were emphasized most due to appearance of the sporophytic stage in this plant. The collection of bryoflora at ground level was done by peeling off from the substratum or ground 
using a simple pocket knife. These specimens were placed in paper packets for further study and to confirm identification at the Natural History Museum in Kathmandu. Kashyap (1972), Gangulee (1969-1980), Chopra (1975), Pradhan (2000), Eddy (1088, 1990,1996), So (1995), Zhu and So (1996) and Smith (1996) were the key literatures consulted for identification. The status categorization was based upon field observation and consulting published records in the Red Data Book of IUCN-Nepal (Tan et al., 2000) and the book by Brummitt and Powell (1992) was consulted to confirm author's citation.

These specimens are deposited at the Natural History Museum in Kathmandu.

\section{RESULTS}

The diversity scale of bryoflora indicated its species variation as per altitudinal gradient. The elevation within the range of 1350 - $2300 \mathrm{~m}$ provided the highest diversity including many rare species. A list of the diversity of this plant is given in the appendix section (appendix I). Species diversity and conservation status of bryofloral of present study is tabulated (table 1) below.

TABLE 1. Diversity and status of bryoflora at different elevation.

\begin{tabular}{l|l|l|l|l}
\hline Elevation $(\mathrm{m})$ & Species diversity & Common species & Rare species & New records \\
\hline $1300-1400 \mathrm{~m}$ & 4 & 4 & $\mathrm{x}$ & $\mathrm{x}$ \\
\hline $1400-1500 \mathrm{~m}$ & 8 & 8 & $\mathrm{x}$ & $\mathrm{x}$ \\
\hline $1500-1600 \mathrm{~m}$ & 19 & 15 & 4 & $\mathrm{x}$ \\
\hline $1600-1700 \mathrm{~m}$ & 20 & 18 & 2 & $\mathrm{x}$ \\
\hline $1700-1800 \mathrm{~m}$ & 18 & 14 & 4 & $\mathrm{x}$ \\
\hline $1800-1900 \mathrm{~m}$ & 19 & 14 & 5 & $\mathrm{x}$ \\
\hline $1900-2000 \mathrm{~m}$ & 12 & 9 & 2 & 1 \\
\hline $2000-2100 \mathrm{~m}$ & 3 & 3 & $\mathrm{x}$ & $\mathrm{x}$ \\
\hline $2100-2200 \mathrm{~m}$ & 6 & 5 & $\mathrm{x}$ & 1 \\
\hline $2200-2300 \mathrm{~m}$ & 14 & 10 & 1 & 3 \\
\hline
\end{tabular}

\section{DISCUSSION}

This study brought a list of 58 species of bryoflora categorized under 39 genera under 27 families and nine orders. The class Hepaticae included 15 genera and 24 species, Anthocerotae with two genera and three species and Musci with 22 genera and 31 species a (appendix I). The species like Jungermannia atrovirens Dumort. Porella arboris-vitae (With.) Grolle, Scapania nemorea (L.) Grolle, Scapania undulata (Sw.ex Lindb.) Dumort and Pogonatum microphyllum (Dozy \& Molk.) Dozy \& Molk. are new additions to country's list. The order Jungermanniales displayed its dominancy with records of 10 species under five families. Jungermannia exertifolia recorded in this study was collected for the first time in Chitwan district of central Nepal (Pradhan, 2014). Heteroscyphus argutus though rare in Chandragiri is fairly common in lowland below $1000 \mathrm{~m}$ of elevation. Similarly, Weissia edentula is a common species in the lowland is rare in this mountain range. 
The elevation of $1600-1700 \mathrm{~m}$ featured an optimal temperature range of $26^{\circ}$ to $27^{\circ} \mathrm{C}$ and favorable moisture content of $80-90 \%$ with display of varied habitat choices like the damp and moist and open and forested areas. Thus this part accommodated a highest diversity of 20 species which drastically decreased at the above range of 2000-2100 m where just three species were recorded. Low humidity content (70 \% and less) and poor representation of habitat preferences are the main causes of species decline in this part. This record included one species of Hepaticae and two species of Musci only. Cyathodium tuberosum (Targioniaceae), Marchantia emarginata, M. paleacea, M. polymorpha (Marchantiaceae), Hydrogonium arcuatum (Pottiaceae), etc. were recorded as fairly common over the entire mountain range. Bryum pachytheca, Pohlia cruda (Bryaceae), Heteroscyphus argutus (Geocalycaceae), Bazzania tricranata (Lepidoziaceae), Pellia calycina (Pelliaceae), Campylopus richardii and Wilsoniella decipiens (Dicranaceae), are the rare species noted in this study. Among five new records made in this study, four species belonged to the order Jungermanniales and one Polytrichales. These were recorded at different elevation habitats. These are Scapania nemorea (L.) Grolle at 1900-2000 m, Porella arboris-vitae (With) Grolle at 2100-2200 m and Jungermannia atrovirens Dumort., Scapania undulata (Sw. ex Lindb.) Dumort and Pogonatum microphyllum (Dozy \& Molk.) Dozy \& Molk. at 2200-2300 m.

Most of the recorded species were noted on mountain slopes intermingled with other bryofloral species and common weeds. Many species of Hepaticae especially the Marchantiales were found growing on soil, rocks and concrete walls. Nine species of epiphytes were recorded on barks and twigs of Alnus, Schima and Castanopsis trees. Of them Bazzania japonica, Bazzania tricranata and Porella arboris-vitae belonged to Jungermanniales of Hepaticae and rest six species were the Musci like Brachythecium buchananii (Hook.) A. Jaeger, Brachythecium wachurae, Plagiomnium succulentum (Mitt.) T.J. Kop., Thuidium haplohymenium (Harv.) A. Jaeger, Thuidium cambifolium (Dozy \& Molk.) Dozy \& Molk. and Thuidium tamariscellum (C. Muell.) Bosch \& Lacey.

Conservation issue of bryoflora in this mountain is a serious concern mainly due to high impact imposed on the potential habitats of this plant by the roadway expansion leading from Thankot (Kathmandu District) to Chitlang of Makwanpur District. This completely has destroyed the habitat of a rare moss called Sauteria spongiosa (Kashyap) S. Hatt. This moss was reported for the first time in this mountain in 1982 (Manandhar, 1982). Its monitoring followed during the year 2010-2012 with the support of Mohamad bin Zayed Species Conservation Fund (Pradhan, 2011) revealed no record of this species due to complete destruction of its only known habitat in the country.

\section{ACKNOWLEDGEMENTS}

The author is very much indebted to the prestigious Mohamed bin Zayed Species Conservation Fund for the generous support to this work. Professor Dr. Bhaiya Khanal of Natural History Museum, Tribhuvan University is acknowledged for his valuable suggestions in this work. I am thankful to Mr. Madan Krishna Shrestha (Zoology), Ms. Suprabha Shrestha and Ms. Sanam Prajapati (Botany) for their accompaniment and significant help during field visits. Mr. Padam Bahadur Tamang of Godam Village of Thankot is also acknowledged for his accompaniment and help in the field. 


\section{ABBREVIATIONS}

BPP Biodiversity Project Profile

C Common

FC Fairly Common

MBZ Mohamed bin Zayed Species Conservation Fund

$\mathrm{R}$

Rare

new records

\section{REFERENCES}

BPP (1995) Biodiversity profile of the tarai/siwalik physiographic zones. BPP Pubs. 12. Department of National Park \& Wildlife Conservation, Kathmandu, Nepal.

BRUMMITT, R K; POWELL, C E (1992) Authors of plant names. Royal Botanic Garden, Kew.

DIXON (1925) Mosses from Mt. Everest expedition (1924) Jour. of Botany London 10: 21-22.

DOBREMEZ, J F (1970) Les grandes divisions phytogeographyque de Nepal et de 1' Himalaya. Bull. Soc. Bot. France 119: 111-120.

DOBREMEZ, J F (1996) Environment and biodiversity. In JHA, P K; GHIMIRE, G P S; BARAL, S B; KARMACHARYA, S R; LACOUL, P (eds) The context of south Asia. Ecological Society, Kathmandu, Nepal; pp. 1-3.

CHOPRA, R S (1975) Taxonomy of Indian mosses. Bot. Monograph 10. Pubs. \& Inf. Directorate, New Delhi, India.

EDDY, A (1988) A Handbook of Malaysian Mosses I. The Nat. Hist. Mus. (BM), London

EDDY, A (1990) A Handbook of Malaysian Mosses II. The Nat. Hist. Mus. (BM), London

EDDY, A (1996) A Handbook of Malaysian Mosses III. The Nat. Hist. Mus. (BM), London

GANGULEE, H C (1969-1980). Mosses of Eastern India and Adjacent Regions. Fasc. 1-8: 1-2145, Pubs. By the author, Kolkata, India.

KASHYAP, S R (1972) Liverworts of western Himalayas and the Panjab plain. Research co. Pubs., Delhi; pp. 1-639.

MANANDHAR, N (1982) Floristic and taxonomic studies of some thalloid liverworts of Kathmandu Valley. M.Sc dissertation, Tribhuvan University, Nepal.

PRADHAN, N (2000) Materials for a checklist of bryophytes of Nepal. Pubs. British Museum, London; pp.1-97.

PRADHAN, N (2010) Bryoflora of lowland Nepal: tarai and churia hills. PhD dissertation, Central Department of Botany, Tribhuvan University, Nepal.

PRADHAN, N (2011) A study on the distribution of Sauteria spongiosa (Kashyap) S. Hatt.: a rare and threatened liverwort and its conservation status in Kathmandu Valley. A project report submitted to MBZ, Abu Dabai, UAE.

PRADHAN, N (2011a) Status and diversity of bryophytes in Nepal. Hamro Sampada 10(8): 40-42.

PRADHAN, N (2013) Diversity and status of bryophytes in Panch Pokhari region of the northern 
Sindhupalchok district of central Nepal. Journal of Natural History Museum 27: 45-58.

PRADHAN, N (2014) Three new records of Jungermannia species (Hepaticae, Jungermanniales) from Nepal. Int. Journ. Envt. 3(1): 85-92.

SMITH, A J E (1996) The liverworts of Britain and Ireland. Cambridge Univ. Press, Cambridge, UK; pp. 1-362.

SO, M.L. (1995) Mosses and liverworts of Hong Kong. Vol.1. Heavenly People Depot. pp. 1-162.

TAN, B C; GEISSLER, P; SODERSTROM, L (2000) The 2000 IUCN World Red List of Bryophytes. IUCN/ SSC bryophytes specialist group mosses, liverworts and hornworts. In Hallingback, T; Hudgetts, N (eds). pp. 77-90.

ZHU, R L; SO, M L (1996) Mosses and liverworts of Hong Kong. Heavenly People Depot, Vol. 2. pp. 1-130. 
Appendix I

Bryophytes diversity of Chandragiri mountain

\begin{tabular}{|c|c|c|c|c|c|}
\hline $\begin{array}{l}\text { Voucher } \\
\text { Number }\end{array}$ & Order & Families & Latin names & $\begin{array}{c}\text { Elevation } \\
(\mathrm{m})\end{array}$ & Status \\
\hline \multicolumn{6}{|c|}{ HEPATICAE } \\
\hline MBZ 76 & Jungermanniales & Geocalycaceae & $\begin{array}{l}\text { Heteroscyphus } \\
\text { argutus (Reinw. \& al.) } \\
\text { Schiffn. }\end{array}$ & 1600 & $R$ \\
\hline MBZ 283 & Jungermanniales & Jungermanniaceae & $\begin{array}{l}\text { *Jungermannia } \\
\text { atrovirens Dumort. }\end{array}$ & 2250 & FC \\
\hline MBZ 366 & Jungermanniales & Jungermanniaceae & $\begin{array}{l}\text { Jungermannia } \\
\text { exertifolia Steph. }\end{array}$ & 1650 & FC \\
\hline MBZ 44 & Jungermanniales & Lepidoziaceae & $\begin{array}{l}\text { Bazzania japonica } \\
\text { (Sande \& Lacey) } \\
\text { Lindb. }\end{array}$ & 2250 & FC \\
\hline MBZ 264a & Jungermanniales & Lepidoziaceae & $\begin{array}{l}\text { Bazzania tricranata } \\
\text { (Wehlendb.) Lindb. }\end{array}$ & 2300 & $R$ \\
\hline MBZ 97 & Jungermanniales & Lepidoziaceae & Bazzania triloba L. & 2200 & C \\
\hline MBZ 38 & Jungermanniales & Plagiochilaceae & $\begin{array}{l}\text { Plagiochila } \\
\text { himalayesis St.cf. }\end{array}$ & $\begin{array}{l}2200- \\
2350\end{array}$ & C \\
\hline MBZ 43 & Jungermanniales & Porellaceae & $\begin{array}{l}\text { *Porella arboris-vitae } \\
\text { (With.) Grolle }\end{array}$ & 2200 & $R$ \\
\hline MBZ 79 & Jungermanniales & Scapaniaceae & $\begin{array}{l}\text { *Scapania nemorea } \\
\text { (L.) Grolle }\end{array}$ & $\begin{array}{l}1900- \\
2000\end{array}$ & FC \\
\hline MBZ 81 & Jungermanniales & Scapaniaceae & $\begin{array}{l}\text { *Scapania undulata } \\
\text { (Sw. ex Lindb.) } \\
\text { Dumort. }\end{array}$ & 2250 & $R$ \\
\hline MBZ 371 & Metzgeriales & Aneuraceae & $\begin{array}{l}\text { Riccardia multifida (L.) } \\
\text { Gray }\end{array}$ & 1550 & FC \\
\hline MBZ 24 & Metzgeriales & Pelliaceae & $\begin{array}{l}\text { Pellia calycina (Tayl.) } \\
\text { Nees }\end{array}$ & 1800 & $R$ \\
\hline $\begin{array}{l}\text { MBZ } \\
49,241\end{array}$ & Marchantiales & Aytoniaceae & $\begin{array}{l}\text { Asterella multiflora } \\
\text { (Steph.) Pande et al. }\end{array}$ & $\begin{array}{l}1650- \\
1950\end{array}$ & FC \\
\hline
\end{tabular}


Pradhan : Altitudinal Distribution of Bryoflora at.

\begin{tabular}{|c|c|c|c|c|c|}
\hline $\begin{array}{l}\text { MBZ 40, } \\
240,252\end{array}$ & Marchantiales & Aytoniaceae & $\begin{array}{l}\text { Asterella wallichiana } \\
\text { (Lehm. \& Lindenb.) } \\
\text { Grolle }\end{array}$ & $\begin{array}{l}1500- \\
1950\end{array}$ & C \\
\hline $\begin{array}{l}\text { MBZ 4, } \\
457\end{array}$ & Marchantiales & Aytoniaceae & $\begin{array}{l}\text { Plagiochasma } \\
\text { appendiculatum Lehm. } \\
\text { \& Lindenb. }\end{array}$ & $\begin{array}{l}1350- \\
1650\end{array}$ & C \\
\hline MBZ 7a & Marchantiales & Aytoniaceae & $\begin{array}{l}\text { Plagiochasma } \\
\text { nepalensis Steph. }\end{array}$ & $\begin{array}{l}2100- \\
2350\end{array}$ & FC \\
\hline MBZ 7b & Marchantiales & Aytoniaceae & $\begin{array}{l}\text { Plagiochasma } \\
\text { pterospermum C. } \\
\text { Massal. }\end{array}$ & $\begin{array}{l}1500- \\
1700\end{array}$ & FC \\
\hline $\begin{array}{l}\text { MBZ 274, } \\
288\end{array}$ & Marchantiales & Conocephalaceae & $\begin{array}{l}\text { Conocephalum } \\
\text { conicum (L.) Underw. }\end{array}$ & 2260 & FC \\
\hline MBZ 1 & Marchantiales & Marchantiaceae & $\begin{array}{l}\text { Marchantia } \\
\text { emarginata Reinw. } \\
\& \text { al. }\end{array}$ & $\begin{array}{l}1400- \\
1850\end{array}$ & C \\
\hline MBZ 223 & Marchantiales & Marchantiaceae & $\begin{array}{l}\text { Marchantia paleacea } \\
\text { Bertols. }\end{array}$ & $\begin{array}{l}1700- \\
1950\end{array}$ & C \\
\hline MBZ 460 & Marchantiales & Marchantiaceae & $\begin{array}{l}\text { Marchantia } \\
\text { polymorpha L. }\end{array}$ & $\begin{array}{l}1500- \\
1850\end{array}$ & C \\
\hline $\begin{array}{l}\text { MBZ 65, } \\
285,287\end{array}$ & Marchantiales & Targioniaceae & $\begin{array}{l}\text { Cyathodium tuberos } \\
\text { Kashyap }\end{array}$ & $\begin{array}{l}1560- \\
2250\end{array}$ & C \\
\hline $\begin{array}{l}\text { MBZ 27, } \\
41\end{array}$ & Marchantiales & Targioniaceae & Targionia hypophylla L. & $\begin{array}{l}2200- \\
2300\end{array}$ & FC \\
\hline MBZ 462 & Marchantiales & Wiesnerellaceae & $\begin{array}{l}\text { Dumortiera hirsuta } \\
\text { (Sw.) Nees. }\end{array}$ & $\begin{array}{l}1350- \\
1500\end{array}$ & C \\
\hline \multicolumn{6}{|c|}{ ANTHOCEROTAE } \\
\hline MBZ 3 & Anthocerotales & Anthocerotaceae & $\begin{array}{l}\text { Anthoceros } \\
\text { chambensis Kashyap }\end{array}$ & $\begin{array}{l}1350- \\
1650\end{array}$ & $\mathrm{FC}$ \\
\hline MBZ 37 & Anthocerotales & Anthocerotaceae & $\begin{array}{l}\text { Anthoceros punctatus } \\
\text { L. }\end{array}$ & $\begin{array}{l}1500- \\
1800\end{array}$ & C \\
\hline $\begin{array}{l}\text { MBZ 53, } \\
55\end{array}$ & Anthocerotales & Anthocerotaceae & $\begin{array}{l}\text { Phaeoceros laevis } \\
\text { (L.) Prosk. }\end{array}$ & $\begin{array}{l}2150- \\
2350\end{array}$ & C \\
\hline \multicolumn{6}{|c|}{ MUSCI } \\
\hline
\end{tabular}




\begin{tabular}{|c|c|c|c|c|c|}
\hline $\begin{array}{l}\text { MBZ 14, } \\
21\end{array}$ & Eubryales & Bartramiaceae & $\begin{array}{l}\text { Philonotis secunda } \\
\text { (Dozy \& Molk.) Bosch } \\
\text { \& Sande Lacey }\end{array}$ & $\begin{array}{l}1800- \\
1900\end{array}$ & C \\
\hline $\begin{array}{l}\text { MBZ 11, } \\
243\end{array}$ & Eubryales & Bartramiaceae & $\begin{array}{l}\text { Philonotis thwaitsii } \\
\text { Mitt. }\end{array}$ & $\begin{array}{l}1500- \\
1900\end{array}$ & C \\
\hline \multirow[t]{2}{*}{ MBZ 247} & Eubryales & Bryaceae & $\begin{array}{l}\text { Bryum apiculatum } \\
\text { Schwaegr. }\end{array}$ & 1820 & $R$ \\
\hline & Eubryales & Bryaceae & $\begin{array}{l}\text { Bryum argenteum } \\
\text { Hedw. }\end{array}$ & $\begin{array}{l}1300- \\
2350\end{array}$ & C \\
\hline MBZ 259 & Eubryales & Bryaceae & $\begin{array}{l}\text { Bryum pachytheca C. } \\
\text { Muell } \\
=\text { Bryum } \\
\text { jumghuhnianum } \\
\text { Dozy\& Molk. }\end{array}$ & 1960 & $R$ \\
\hline MBZ 364 & Eubryales & Bryaceae & $\begin{array}{l}\text { Pohlia cruda (Hedw.) } \\
\text { Linbd. }\end{array}$ & 1650 & $R$ \\
\hline MBZ 301, & Eubryales & Bryaceae & $\begin{array}{l}\text { Pohlia elongate } \\
\text { Hedw. }\end{array}$ & 1950 & FC \\
\hline $\begin{array}{l}\text { MBZ 96, } \\
393\end{array}$ & Eubryales & Mniaceae & $\begin{array}{l}\text { Plagiomnium } \\
\text { succulenteum (Mitt.) } \\
\text { T. Kop }\end{array}$ & $\begin{array}{l}2200- \\
2300\end{array}$ & C \\
\hline MBZ 16 & Eubryales & Dicranaceae & $\begin{array}{l}\text { Campylopodium } \\
\text { khasianum (Griff.) } \\
\text { Paris }\end{array}$ & 1800 & FC \\
\hline MBZ 230 & Eubryales & Dicranaceae & $\begin{array}{l}\text { Campylopus richardii } \\
\text { Brid. }\end{array}$ & $\begin{array}{l}1800- \\
1850\end{array}$ & $R$ \\
\hline MBZ 13 & Eubryales & Dicranaceae & $\begin{array}{l}\text { Trematodon longicollii } \\
\text { Michx. }\end{array}$ & $\begin{array}{l}1500- \\
1600\end{array}$ & FC \\
\hline MBZ 17 & Eubryales & Dicranaceae & $\begin{array}{l}\text { Wilsoniella decipiens } \\
\text { (Mitt.) Aist. }\end{array}$ & 1800 & $R$ \\
\hline MBZ 22 & Funariales & Funariaceae & $\begin{array}{l}\text { Entosthodon wallichii } \\
\text { Mitt. }\end{array}$ & $\begin{array}{l}1500- \\
1650\end{array}$ & FC \\
\hline MBZ 5, 10 & Funariales & Funariaceae & $\begin{array}{l}\text { Funaria hygrometrica } \\
\text { Hedw. }\end{array}$ & $\begin{array}{l}1400- \\
1800\end{array}$ & C \\
\hline
\end{tabular}


Pradhan : Altitudinal Distribution of Bryoflora at.

\begin{tabular}{|c|c|c|c|c|c|}
\hline MBZ 253 & Funariales & Funariaceae & $\begin{array}{l}\text { Physcomitrium } \\
\text { pyriformae (Hedw.) } \\
\text { Hampe }\end{array}$ & 1800 & $R$ \\
\hline MBZ 25 & Hypnobryales & Brachytheciaceae & $\begin{array}{l}\text { Brathythecium } \\
\text { buchananii (Hook.) A. } \\
\text { Jaeger }\end{array}$ & 2350 & FC \\
\hline MBZ 11 & Hypnobryales & Brachytheciaceae & $\begin{array}{l}\text { Brathythecium } \\
\text { wichurae Broth. }\end{array}$ & 1600 & $R$ \\
\hline $\begin{array}{l}\text { MBZ } \\
209,220, \\
254,356, \\
256\end{array}$ & Hypnobryales & Hypnaceae & $\begin{array}{l}\text { Hypnum pleumaforme } \\
\text { W. Wilson }\end{array}$ & $\begin{array}{l}1850- \\
1950\end{array}$ & C \\
\hline MBZ 226 & Hypnobryales & Hypnaceae & $\begin{array}{l}\text { Ptilium crista- } \\
\text { cristensis (Hedw.) De } \\
\text { Not. }\end{array}$ & $\begin{array}{l}1450- \\
1880\end{array}$ & FC \\
\hline MBZ 363 & Hypnobryales & Plagiotheciaceae & $\begin{array}{l}\text { Plagiothecium } \\
\text { neckroidium B.S.G }\end{array}$ & $\begin{array}{l}1600- \\
1780\end{array}$ & FC \\
\hline MBZ 361 & Hypnobryales & Rhytidiaceae & $\begin{array}{l}\text { Rhytidium rugosum } \\
\text { (Hedw.) Kindb. }\end{array}$ & 1650 & $R$ \\
\hline MBZ 369 & Hypnobryales & Sematophyllaceae & $\begin{array}{l}\text { Foreaulla orthothecia } \\
\text { (Schwaegr.) Dix. \& } \\
\text { Verd. }\end{array}$ & 1600 & $R$ \\
\hline MBZ 242 & Hypnobryales & Thuidaceae & $\begin{array}{l}\text { Thuidium cambifolium } \\
\text { (Dozy \& Molk.) Dozy } \\
\text { \& Molk. }\end{array}$ & $\begin{array}{l}1900- \\
2000\end{array}$ & C \\
\hline MBZ 250 & Hypnobryales & Thuidaceae & $\begin{array}{l}\text { Thuidium glaucinum } \\
\text { (Mitt.) Bouch. \& } \\
\text { Lacey }\end{array}$ & 1870 & $R$ \\
\hline MBZ 372 & Hypnobryales & Thuidaceae & $\begin{array}{l}\text { Thuidium } \\
\text { haplohymenium } \\
\text { (Harv.) A. Jaeger }\end{array}$ & 2300 & FC \\
\hline MBZ 358 & Polytrichales & Polytrichaceae & $\begin{array}{l}\text { Pogonatum commune } \\
\text { Hedw. }\end{array}$ & $\begin{array}{l}1800- \\
2100\end{array}$ & C \\
\hline MBZ 273 & Polytrichales & Polytrichaceae & $\begin{array}{l}\text { *Pogonatum } \\
\text { microphyllum (Dozy \& } \\
\text { Molk.) Dozy \& Molk. }\end{array}$ & 2250 & $R$ \\
\hline
\end{tabular}




\begin{tabular}{|l|l|l|l|l|l|}
\hline MBZ 80 & Pottiales & Pottiaceae & $\begin{array}{l}\text { Anoectangium clarum } \\
\text { Mitt. }\end{array}$ & 1850 & C \\
\hline MBZ 253 & Pottiales & Pottiaceae & $\begin{array}{l}\text { Anoectangium } \\
\text { stracheyanum Mitt. }\end{array}$ & 1900 & R \\
\hline $\begin{array}{l}\text { MBZ 254, } \\
\text { 258, 277 }\end{array}$ & Pottiales & Pottiaceae & $\begin{array}{l}\text { Hydrogonium } \\
\text { arcuatum (Griff.) Wijk. } \\
\text { \& Marg. }\end{array}$ & $\begin{array}{l}1600- \\
1900\end{array}$ & C \\
\hline $\begin{array}{l}\text { MBZ 261, } \\
\text { 266 }\end{array}$ & Pottiales & Pottiaceae & Weissia edentula Mitt. & $\begin{array}{l}1500- \\
1950\end{array}$ & R \\
\hline
\end{tabular}

